\title{
Kajian Sifat Fisika-Kimia Air Bahang dan Indeks Pencemaran di Perairan PLTU Sumbawa Barat
}

\author{
${ }^{1}$ Amirul Hilmi, ${ }^{2}$ Andi Maria Ulfa, ${ }^{3}$ Muh Iman Darmawan \\ ${ }^{1}$ Prodi Teknik Industri, Fakultas Teknik, Universitas Cordova. Jln. Pd. Pesantren, Menala, \\ Taliwang, No.112, Kabupaten Sumbawa Barat, NTB, 84355, \\ ${ }^{2}$ Prodi Pemanfaatan Sumberdaya Perikanan, Fakultas Pertanian, Universitas Cordova. Jln. Pd. \\ Pesantren, Menala, Taliwang, No.112, Kabupaten Sumbawa Barat, NTB, 84355, \\ ${ }^{3}$ Prodi Teknik Lingkungan, Fakultas Teknik, Universitas Hamzanwadi, Jln. TGKH. M. \\ Zainuddin Abdul Madjid No. 132 Pancor Selong, Lombok Timur, NTB, 83611 \\ Email: hilmi.alguntimy@gmail.com,yayaqe06011991@gmail.com, \\ darmawan240290@gmail.com
}

\begin{tabular}{|c|c|}
\hline & \\
\hline & \multirow[b]{2}{*}{$\begin{array}{l}\text { This research examines the physical and chemical properties of the potential } \\
\text { contamination of condenser cooling water (heat water) at the } 2 x 7 \mathrm{MW} \text { West } \\
\text { Sumbawa Steam Power Plant. Method's this research is direct observation in } \\
\text { the field. The determination of the sample point was done by purposive } \\
\text { sampling. The results showed that the hot water had met the predetermined } \\
\text { quality standards, namely a pH of } 8.21 \text {, a temperature of } 38.5^{\circ} \mathrm{C} \text { and a } \\
\text { content of free chlorine (Cl2) of } 0.03 \mathrm{mg} / \mathrm{L} \text {. There was an increase in sea } \\
\text { water temperature in a radius of } 17 \mathrm{~meters} \text { east and west by } 8^{0} \mathrm{C} \text { from } 28^{\circ} \mathrm{C} \text { to } \\
36^{\circ} \mathrm{C} \text {. Direct discharge of hot water has the potential to pollute the marine } \\
\text { prawn environment around the } 2 x 7 \mathrm{MW} \text { West Sumbawa PLTU. From the } \\
\text { results of the study, it was found that the temperature of the hot water had met } \\
\text { the specified quality standard, which was } 40 o C \text {, but direct disposal caused } \\
\text { the sea water temperature to rise, exceeding the set sea water temperature } \\
\text { quality standard of } 32^{\circ} \mathrm{C} \text { and the temperature increase should not be more } \\
\text { than } 2^{\circ} \mathrm{C} \text { from the temperature. at first. The status of sea water quality due to } \\
\text { the entry of hot water is determined using a pollution index. From the } \\
\text { calculation results obtained PIj of } 1.125 \text { at the sample point Outfall } 2 \text {, } \\
\text { meaning that the sea water conditions at a radius of } 17 \text { meters are lightly } \\
\text { polluted. As a form of control and prevention of pollution due to the entry of } \\
\text { high temperature hot water, continuous monitoring is necessary and it is } \\
\text { necessary to create a mixing pool between sea water and hot water before the } \\
\text { heat is discharged into the sea. }\end{array}$} \\
\hline $\begin{array}{l}\text { Keywords } \\
\text { Physical-chemical } \\
\text { properties; hot water; } \\
\text { pollution index; west } \\
\text { Sumbawa }\end{array}$ & \\
\hline & \\
\hline & \multirow{2}{*}{$\begin{array}{l}\text { Penelitian ini mengkaji sifat fisika dan kimia dalam potensi pencemaran air } \\
\text { pendingin kondensor (air bahang) di Pembangkit Listrik Tenaga Uap } \\
\text { Sumbawa Barat } 2 \times 7 \mathrm{MW} \text {. Metode penelitian ini yaitu obeservasi secara } \\
\text { langsung di lapangan. Penentuan titik sampel dilakukan secara purposive } \\
\text { sampling. Hasil penelitian menunjukkan bahwa air bahang sudah memenuhi } \\
\text { baku mutu air bahang yang sudah ditetapkan yaitu pH sebesar } 8,21 \text {, suhu } \\
\text { sebesar } 38,5^{\circ} \mathrm{C} \text { dan kadar klorin bebas }\left(\mathrm{Cl}_{2}\right) \text { sebesar } 0,03 \mathrm{mg} / \mathrm{L} \text {. Terjadi } \\
\text { kenaikan suhu air laut di radius } 17 \text { meter arah timur dan barat sebesar } 8^{\circ} \mathrm{C} \text { dari } \\
28^{\circ} \mathrm{C} \text { menjadi } 36^{\circ} \mathrm{C} \text {. Pembuangan air bahang secara langsung berpotensi }\end{array}$} \\
\hline & \\
\hline
\end{tabular}


mencemari lingkungan perairan laut di sekitar PLTU Sumbawa Barat 2x7 MW. Dari hasil penelitian diperoleh suhu air bahang sudah memenuhi baku mutu yang ditetapkan yaitu sebesar $40^{\circ} \mathrm{C}$, akan tetapi pembuangan secara langsung mengakibatkan suhu air laut menjadi naik, melebihi baku mutu suhu air laut yang ditetapkan yaitu sebesar $32^{\circ} \mathrm{C}$ dan kenaikan suhu tidak boleh lebih dari $2^{\circ} \mathrm{C}$ dari suhu mula-mula. Status mutu air laut akibat masuknya air bahang ditentukan dengan menggunakan indeks pencemaran. Dari hasil perhitungan diperoleh $\mathrm{PI}_{\mathrm{j}}$ sebesar 1,125 di titik sampel Outfall 2, artinya kondisi air laut pada radius 17 meter mengalami pencemaran ringan. Sebagai bentuk pengendalian dan pencegahan pencemaran akibat masuknya air bahang yang bersuhu tinggi maka perlu dilakukan pemantauan secara terus menerus dan perlu dibuat kolam pencampur antara air laut dengan air bahang sebelum air bahang dibuang ke laut.

Sitasi: Hilmi, A., Ulfa, A. M., \& Darmawan, M. I. (2021). Kajian Sifat Fisika-Kimia Air Bahang dan Indeks Pencemaran di Perairan PLTU Sumbawa Barat. Kappa Journal, 5(1), 57-67.

\section{PENDAHULUAN}

Keberadaan Pembangkit Listrik Tenaga Uap (PLTU) memberikan dampak positif dan negatif baik dari sisi sosial, budaya, ekonomi dan lingkungan. Dari sisi sosial ekonomi, keberadaan PLTU dapat menyediakan lapangan pekerjaan bagi masyarakat di sekitar kawasan PLTU. Sementara itu, keberadaan PLTU dapat memberikan dampak negatif terhadap lingkungan. Dibutuhkan upaya-upaya dalam penangan dampak lingkungan, mulai dari perencanaan, analisis dan monitoring, baik secara internal maupun secara eksternal (Choi, Keun-Hyung:2012). Secara internal pihak PLTU diharapkan untuk selalu memonitor limbah yang dihasilkan, mengelola limbah dengan baik sebelum dibuang sehingga memenuhi ambang batas yang sudah ditentukan Undang-Undang dan peraturan menteri lingkungan hidup. Secara eksternal, pihak dinas terkait harus bertindak aktif untuk memonitoring kegiatan PLTU. Dalam pengoperasian PLTU baik yang menggunakan bahan bakar batubara, gas, minyak bumi ataupun nuklir, umumnya menggunakan air laut sebagai pendingin utamanya. Air laut yang digunakan untuk mendinginkan kondensor kemudian dibuang ke laut secara langsung. Air buangan pendingin PLTU (air bahang) biasanya akan mengalami kenaikan suhu ketika melewati kondensor (Effendi, H.: 2003). Laju perpindahan air pendingin harus lancer, karena jika terganggu maka akan berpengaruh pada tekanan dan temperatur (PT. PLN Pusdiklat, 2005). Air panas dapat menyebabkan penurunan kualitas perairan sehingga mempengaruhi kehidupan biota perairan khususnya plankton (Hafid dkk: 2014).

Pemenuhan kebutuhan listrik dengan pengoperasian PLTU Sumbawa Barat 2x7 MW, disisi lain menghasilakan air buangan (air bahang) yang langsung dibuang secara sirkular ke laut. Pembuangan air panas secara langsung ke perairan dapat mempengaruhi ekosistem perairan dan perubahan komunitas organisme laut. Dalam Keputusan Menteri Lingkungan Hidup No.51 Tahun 2004 menyebutkan kenaikan suhu perairan oleh aktivitas industri tidak lebih dari $2^{\circ} \mathrm{C}$ dari suhu perairan. Sedangkan pada Peraturan Menteri Negara Lingkungan Hidup Nomor 08 Tahun 2009 tentang Baku Mutu Air Limbah Bagi Usaha dan Atau Kegiatan Pembangkit Listrik Tenaga Termal Sumber Kegiatan Pendukung Point A, yaitu Sumber Pendingin (Air Bahang), menyebutkan kadar maksimum Temperatur air bahang maksimum $40^{\circ} \mathrm{C}$ dan Kadar Klorin Bebas $\left(\mathrm{Cl}_{2}\right)$ maksimum 0,5 mg/L. 
Dalam rangka pengendalian pencemaran lingkungan akibat pembuangan air pendingin (air bahang) PLTU Sumbawa Barat 2x7 MW perlu dilakukan pengecakan secara rutin sehingga suhu air pendingin tidak melebihi ambang batas yang sudah ditetapkan dalam Permen LH No. 8 tahun 2009. Tujuan dari penelitian ini yaitu untuk mengetahui sifat fisikakimia air pendingin kondensor Pembangkit Listrik Tenaga Uap serta untuk mengetahui potensi pencemaran akibat pembuangan air pendingin Pembangkit Listrik Tenaga Uap.

\section{METODE}

Sampel dalam penelitian ini adalah air bahang dari PLTU Sumbawa Barat 2x7 MW. Penentuan dan teknik pengambilan sampel dilakukan dengan teknik purposive sampling, dengan pertimbangan bahwa PLTU Sumbawa Barat 2x7 MW adalah satu-satunya PLTU yang beroperasi di wilayah Kabupaten Sumbawa Barat, dan penentuan titik sampling dilakukan berdasarkan kemudahan pengambilan sampel yaitu pada sampling rate Inlet Condenser, Outlet Condenser dan saluran pembuangan air bahang, seperti pada Gambar1.
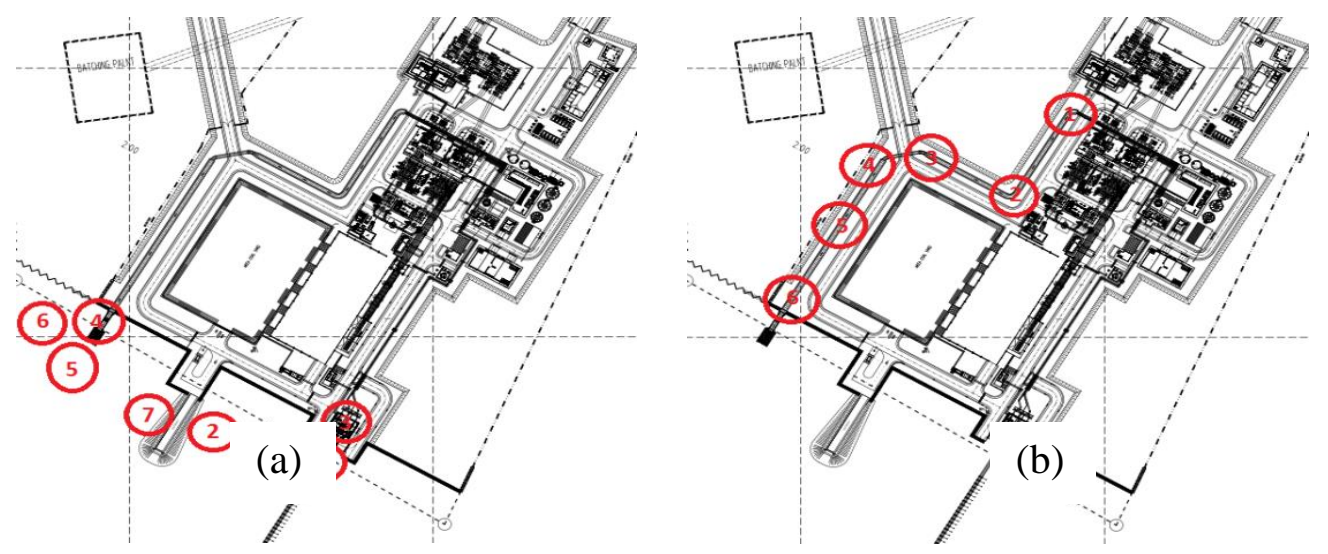

Gambar 1. Lokasi sampling air laut (a) dan lokasi sampling air bahang (b)

Selain di kondensor, sampel air laut juga diambil di 7 titik yaitu Intake 1, Intake 2, Kolam Intake, Outfall 1, Outfall 2, Outfall 3, Outfall 4. Lokasi sampling dapat dilihat pada Gambar 1 dan Tabel 1.

Tabel 1. Titik sampel air laut

\begin{tabular}{|cll|}
\hline No & \multicolumn{1}{|c|}{ Titik Sampel } & \multicolumn{1}{c|}{ Keterangan } \\
\hline 1. & Intake 1 & berlokasi di atas pipa intake air laut \\
\hline 2. & Intake 2 & berlokasi di sebelah timur dermaga \\
\hline 3. & Kolam Intake & berlokasi di kolam penampungan air laut \\
\hline 4. & Outfall 1 & berlokasi di ujung mulut saluran pembuangan air bahang \\
\hline 5. & Outfall 2 & $\begin{array}{l}\text { berlokasi di pinggir pantai yang berhadapan langsung dengan } \\
\text { saluran pembuangan air bahang }\end{array}$ \\
\hline 6. & Outfall 3 & $\begin{array}{l}\text { berlokasi di pinggir pantai sebelah barat saluran pembuangan } \\
\text { air bahang }\end{array}$ \\
\hline 7. & Outfall 4 & berlokasi di sebelah barat dermaga \\
\hline
\end{tabular}


Metode pengumpulan data yang dilakukan yaitu survei primer, berupa pengukuran suhu di lapangan, dan pengukuran $\mathrm{pH}$ dan kadar klorin bebas $\left(\mathrm{Cl}_{2}\right)$ di laboratorium. Adapun alat yang digunakan dalam penelitian ini yaitu, termometer raksa, $\mathrm{pH}$ meter digital HK-3C dan Free and Total Chlorine portable photometer HI96711. Bahan yang digunakna dalam penelitian ini yaitu, sampel Inlet Condenser dan Outlet Condenser, aquades, HI93701-01 Free Chlorine Reagent.

Untuk mengetahui potensi pencemaran dan status pencemaran digunakan indeks pencemaran seperti yang termuat dalam Peraturan Keputusan Menteri Lingkungan Hidup No.51 Tahun 2004, yaitu dengan menggunakan persamaan:

$$
P I_{j}=\sqrt{\frac{\left(C_{i} / L_{i j}\right)_{M}^{2}+\left(C_{i} / L_{i j}\right)_{R}^{2}}{2}}
$$

Diamana:

$\mathrm{L}_{\mathrm{i}} \quad$ : Konsentrasi parameter kualitas air dalam baku mutu

$\mathrm{C}_{\mathrm{i}} \quad$ : Konsentrasi parameter kualitas air hasil survei

$\mathrm{PI}_{\mathrm{j}} \quad$ : Indeks pencemaran bagi peruntukan

$\left(\mathrm{C}_{\mathrm{i}} / \mathrm{L}_{\mathrm{ij}}\right)_{\mathrm{M}} \quad$ : Nilai $\mathrm{C}_{\mathrm{i}} / \mathrm{L}_{\mathrm{ij}}$ Maksimum

$\left(\mathrm{C}_{\mathrm{i}} / \mathrm{L}_{\mathrm{ij}}\right)_{\mathrm{R}} \quad$ : Nilai $\mathrm{C}_{\mathrm{i}} / \mathrm{L}_{\mathrm{ij}}$ Rata-rata

Hubungan antara tingkat ketercemaran dengan indeks pencemaran terkait status mutu air sebagai berikut:

1. $0 \leq \mathrm{PI}_{\mathrm{j}} \leq 1,0 \quad$ : Memenuhi baku mutu (kondisi baik)

2. $1,0 \leq \mathrm{PI}_{\mathrm{j}} \leq 5,0 \quad$ : Tercemar ringan

3. $5,0 \leq \mathrm{PI}_{\mathrm{j}} \leq 10 \quad$ : Tercemar sedang

4. $\mathrm{PI}_{\mathrm{j}}>10 \quad$ : Tercemar berat

\section{HASIL DAN PEMBAHASAN}

Penelitian dimulai dari pengukuran suhu pada air laut dan kolam intake air laut sebelum pengoperasian PLTU Sumbawa Barat 2x7 MW untuk mengetahui suhu perairan sebelum masuknya air bahang. Sampel diambil di tujuh titik sampel mulai dari kolam intake air laut sampai sekitar ujung saluran buangan air bahang, yaitu pada radius \pm 56 meter arah timur dan barat. Suhu air laut yang dikur akan menjadi acuan dalam menentukan potensi pencemaran air panas oleh masuknya air bahang ke perairan laut di sekitar PLTU Sumbawa Barat 2x7 MW. Potensi pencemaran dapat ditentukan dengan naiknya suhu perairan. Penggunaan air pendingin satu kali lewat (once through system) memiliki tingkat bahaya yang lebih besar dibandingkan dengan sistem tertutup karena air panas yang melewati kondensor langsung dialirkan ke laut (Fleishcli dkk, 2014).

Pada saat PLTU Sumbawa Barat 2x7 MW beroperasi, dilakukan pengukuran $\mathrm{pH}$, suhu dan kadar klorin bebas $\left(\mathrm{Cl}_{2}\right)$ pada outfall condenser untuk mengetahui kondisi aktual apakah air bahang sudah memenuhi standar baku mutu air limbah termal yang sudah ditetapkan dalam perundang-undangan. Pengukuran suhu air bahang dilakukan mulai dari outfall condenser kemudian di saluran buangan air bahang dan air laut di sekitar ujung saluran buangan air bahang. Hasil pengukuran ini dapat dijadikan sebagai bentuk pengendalian pencemaran air laut oleh masuknya air bahang. Selain itu, pengukuran suhu air bahang untuk mengetahui sebaran suhu air bahang, sehingga dapat diketahui sejauh mana air 
bahang masuk ke perairan dan seberapa besar kenaikan suhu perairan sekitar. Peta sebaran air bahang dibuat dengan menggunakan software surfer 8. Peta dibuat berdasarkan titik koordinat tempat sampel diambil dan data suhu, surfer secara otomatis melakukan interpolasi data.

\subsection{Sifat Fisika Kimia Air Pendingin Kondensor}

Dalam rangka pengendalian pencemaran air, maka perlu dilakukan monitoring sehingga limbah air bahang yang dibuang memenuhi baku mutu yang sudah ditetapkan. Berdasarkan Peraturan Menteri Negara Lingkungan Hidup Nomor 08 Tahun 2009 tentang Baku Mutu Air Limbah Bagi Usaha dan Atau Kegiatan Pembangkit Listrik Tenaga Termal, bahwa suhu air bahang yang diperbolehkan maksimum $40^{\circ} \mathrm{C}$ dengan kadar klorin bebas $\left(\mathrm{Cl}_{2}\right)$ sebesar $0,5 \mathrm{mg} / \mathrm{L}$.

Air bahang merupakan air pendingin yang sudah melewati kondensor, umumnya air yang sudah melewati kondensor akan mengalami peningkatan suhu. Pada PLTU Sumbawa Barat 2x7 MW, air pendingin kondensor yang digunakan yaitu air laut. Jadi air laut dipompakan melewati kondensor dan langsung dibuang ke laut. Dimana air laut yang digunakan sudah diinjeksikan klorin (klorinasi) untuk memabukkan biota laut dan mencegah terjadinya pengerakan pada pipa saluran air pendingin. Jika mikroorganisme berkembang biak dan menempel didinding pipa saluran air pendingin maka akan menyebabkan perubahan laju aliran air pendingin yang dapat menyebabkan penurunan kinerja dari kondensor. Sampel air bahang diambil pada inlet kondensor dan outlet kondensor. Pengambilan pada dua titik ini akan memberikan gambaran sejauh mana kinerja dari kondesnor dan seberapa besar kenaikan suhu air pendingin setelah melewati kondensor. Parameter yang penting untuk dijaga yaitu $\mathrm{pH}$, suhu dan kadar klorin bebas $\left(\mathrm{Cl}_{2}\right)$ (Simanjuntak, 2009). Data hasil pengukuran $\mathrm{pH}$, suhu dan klorin bebas $\left(\mathrm{Cl}_{2}\right)$ air bahang dapat dilihat pada Tabel 2 .

Dari penelitian diperoleh bahwa $\mathrm{pH}$ air bahang rata-rata sebesar 8,21. Nilai $\mathrm{pH}$ air bahang ini termasuk nilai yang normal sehingga ketika air bahang dibuang langsung ke laut tidak akan menaikkan nilai $\mathrm{pH}$ air laut. Dimana $\mathrm{pH}$ yang sangat basa dapat membahayakan kelangsungan hidup organisme karena akan mengganggu proses metabolisme dan respirasi (Hamuna dkk. 2018). Variasi nilai pH juga berpengaruh pada biota perairan (Megawati dkk, 2014).

Tabel 2. Sifat Fisika Kimia Air Bahang pada Outlet Kondensor

\begin{tabular}{cccc}
\hline No & $\mathbf{p H}$ & $\begin{array}{r}\text { Temperatur } \\
\left({ }^{\mathbf{}} \mathbf{C}\right)\end{array}$ & $\begin{array}{c}\text { Klorin Bebas }\left(\mathbf{C l}_{2}\right) \\
(\mathbf{p p m})\end{array}$ \\
\hline 1. & 8,24 & 36 & 0,07 \\
2. & 8,22 & 36 & 0,05 \\
3. & 8,21 & 38 & 0,03 \\
4. & 8,20 & 44 & 0,01 \\
5. & 8,24 & 42 & 0,02 \\
6. & 8,15 & 38 & 0,01 \\
\hline
\end{tabular}




\begin{tabular}{cccc}
7. & 8,20 & 36 & 0,04 \\
8. & 8,20 & 36 & 0,03 \\
9. & 8,22 & 39 & 0,05 \\
10. & 8,24 & 40 & 0,03 \\
Rata-rata & 8,21 & 38,5 & 0,03 \\
\hline
\end{tabular}

Data hasil pengukuran $\mathrm{pH}$ dan suhu pada inlet kondensor dan outlet kondensor. Perubahan $\mathrm{pH}$ dan suhu air pendingin sebelum melewati kondensor dan setelah melewati kondensor dapat dilihat pada Gambar 2. dan Gambar 3.

Dari grafik pada Gambar 2. menunjukkan bahwa terjadi kenaikan $\mathrm{pH}$ air laut yang digunakan sebagai pendingin ketika melewati outlet condenser. Kenaikan $\mathrm{pH}$ ini dipengaruhi oleh naiknya suhu air bahang. Berdasarkan Kepmen LH No.51 Tahun 2004, nilai $\mathrm{pH}$ ini masih dalam rentang $\mathrm{pH}$ yang diperbolehkan untuk air laut, sehingga ketika air bahang dibuang tidak akan mencemari air laut sekitar PLTU Sumbawa Barat 2x7 MW.

Hasil pengukuran suhu pada inlet condenser dan outlet condenser menunjukkan nilai yang fluktuatif, nilainya berkisar antara $36-44{ }^{\circ} \mathrm{C}$. Selama satu bulan penelitian terjadi kenaikan suhu yang melebihi ambang batas baku mutu air bahang yang sudah ditetapkan, yaitu pada pengambilan ke- 4 dan ke- 5, nilainya lebih dari $40^{\circ} \mathrm{C}$. Dimana dalam Peraturan Menteri Negara Lingkungan Hidup Nomor 08 Tahun 2009 suhu air bahang yang maksimum $40^{\circ} \mathrm{C}$. Suhu merupakan faktor yang dapat mempengaruhi aktivitas metabolisme dan penyebaran organisme air, pengukuran suhu perairan penting dilakukan untuk menjaga kondisi ideal suatu perairan (Nontji, 2005)

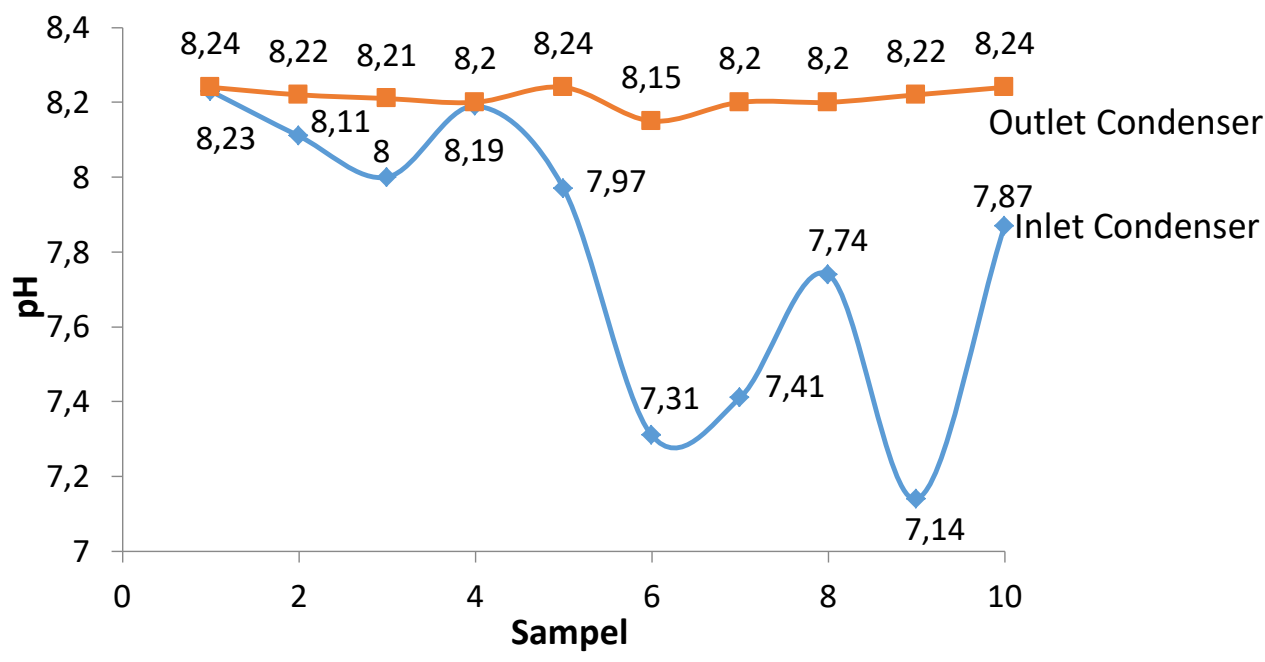

Gambar 2. pH Inlet Condenser dan pH Outlet Condenser

Kenaikan suhu air bahang berkisar antara 2-6 ${ }^{\circ} \mathrm{C}$ ketika melewati kondensor. Perbedaan kenaikan suhu diakibatkan oleh aktivitas kerja kondensor dan kondisi air laut yang digunakan untuk pendingin kondensor. 


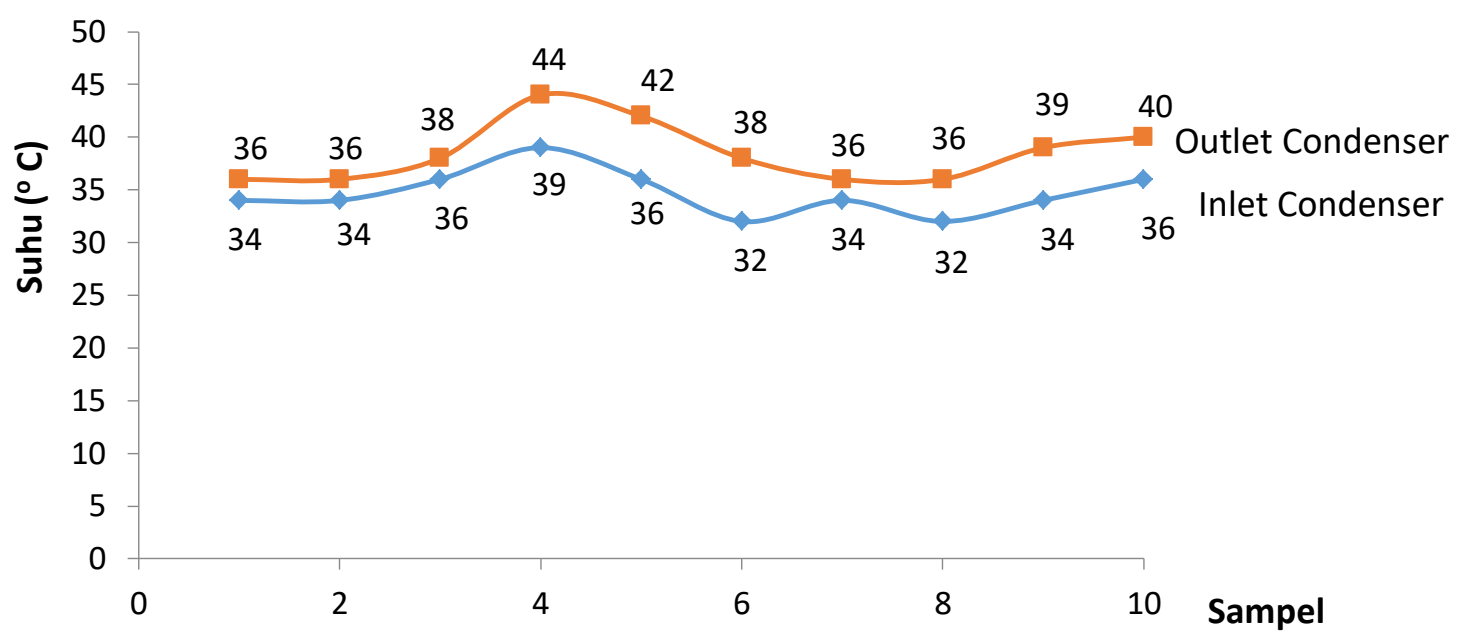

Gambar 3. Suhu air pendingin di Inlet Condenser dan Outlet Condenser

\subsection{Sebaran Suhu Air Bahang dan Potensi Pencemaran Air Bahang}

Pada penelitian ini untuk mengetahui sebaran suhu air bahang dan penurunan suhu air bahang maka dilakukan pengukuran suhu air bahang mulai dari outlet condenser sampai ke laut, penejelasan mengenai letak titik sampel dapat dilihat di Tabel 1. Di setiap titik pengambilan ditentukan titik koordinatnya dan dilakukan proses pemetaan sebaran suhu air bahang dari unit Kondensor PLTU Sumbawa Barat 2x7 MW sampai di perairan laut di sekitar PLTU Sumbawa Barat 2x7 MW. Penentuan koordinat penting dilakukan sehingga memudahkan dalam membuat peta sebaran suhu air bahang. Data suhu air bahang dan titik koordinat pengambilan sampel dapat dilihat pada Tabel 3.

Tabel 3. Sebaran Suhu Air Bahang

\begin{tabular}{lcccc}
\hline \multirow{2}{*}{ Titik Sampel } & Kode & Temperatur $\left({ }^{\mathbf{o}} \mathbf{C}\right)$ & \multicolumn{2}{c}{ Koordinat UTM } \\
& Sampel & & $\mathbf{x}$ & $\mathbf{Y}$ \\
\hline Oulet Kondensor & OC & 38.5 & 475588 & 9033731 \\
AB1 & AB1 & 38 & 475557 & 9033731 \\
AB2 & AB2 & 37 & 475526 & 9033701 \\
AB3 & AB3 & 37 & 475465 & 9033731 \\
AB4 & AB4 & 36 & 475435 & 9033731 \\
AB5 & AB5 & 36 & 475404 & 9033670 \\
AB6 & AB6 & 36 & 475343 & 9033608 \\
Intake 1 & IN1 & 28 & 475466 & 9033455 \\
Intake 2 & IN2 & 28 & 475435 & 9033516 \\
Kolam Intake & KI & 30 & 475496 & 9033516 \\
Outfall 1 & OUT1 & 36 & 475343 & 9033608 \\
Outfall 2 & OUT2 & 36 & 475374 & 9033578 \\
Outfall 3 & OUT3 & 30 & 475313 & 9033608 \\
Outfall 4 & OUT4 & 30 & 475404 & 9033547 \\
\hline
\end{tabular}

Dari Tabel 3. dapat dilihat bahwa terjadi penurunan suhu air bahang mulai dari outfall condenser yang nilainya rata-rata $38,5{ }^{\circ} \mathrm{C}$ turun secara berangsur-angsur menjadi 
36 pada ujung saluran buangan air bahang. Dimana panjang saluran pembuangan air bahang yaitu 303,26 meter. Dari hasil penelitian dapat dilihat bahwa panjang saluran tidak cukup panjang untuk menurunkan suhu air bahang. Walaupun air bahang yang dihasilkan sudah memenuhi baku matu air bahang yaitu maksimum sebesar $40^{\circ} \mathrm{C}$, tetapi masih terlalu tinggi untuk dibuang ke laut karena dapat menaikkan suhu air laut. Pola sebaran air panas dapat diakibatkan oleh pola sirkulasi laut yang dikendalikan oleh gaya pasang surut (Fikri, 2018).

Sebagai bentuk pencegahan masukknya air bahang yang memiliki suhu tinggi yang dapat berpotensi menaikkan suhu air laut dan mencemari air laut maka perlu dibuat kolam pencampur antara air laut dengan air bahang. Air bahang tidak dibuang langsung ke laut tetapi dialirkan terlebih dahulu ke dalam kolam pencampur.

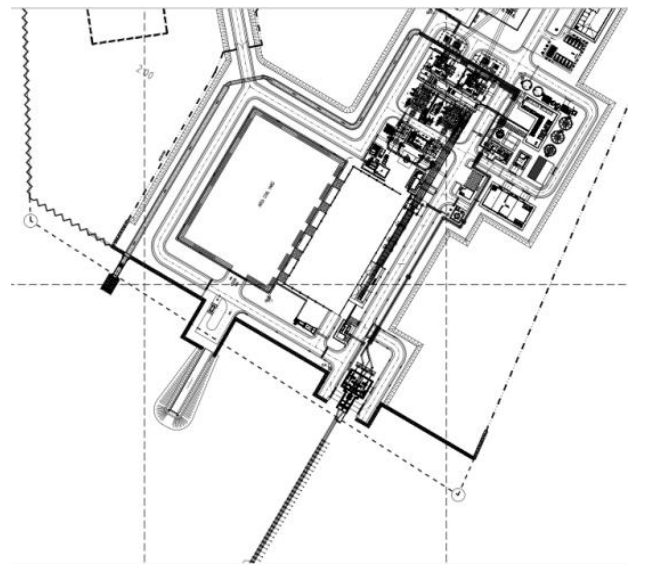

(a)

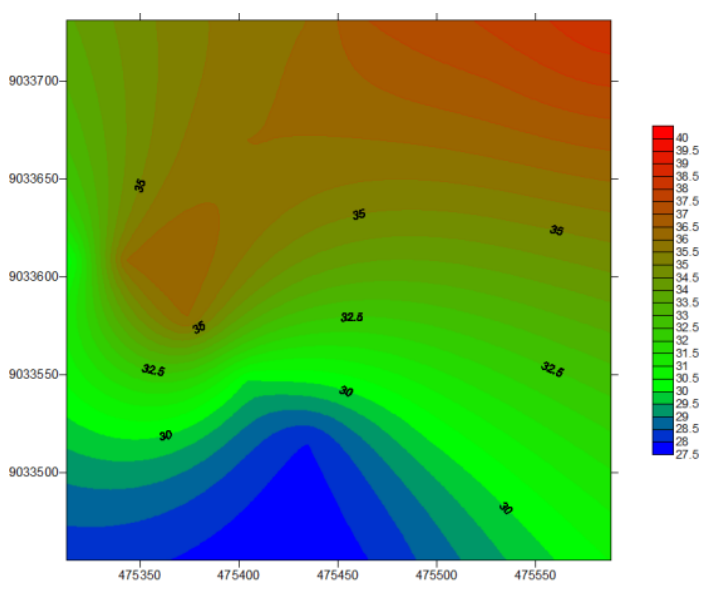

(b)

Gambar 4. Plane PLTU Sumbawa Barat 2x7 MW (a) dan peta sebaran suhu air bahang PLTU Sumbawa Barat 2x7 MW (b).

Suhu perairan merupakan salah satu faktor penting dalam kehidupan organisme perairan. Suhu merupakan parameter yang sangat gampang diukur. Untuk mengetahui kondisi periaran dapat dengan mudah dilakukan yaitu dengan mengukur suhu perairan.

Pada penelitian ini dilakukan pengukuran suhu air laut di sekitar PLTU Sumbawa Barat 2x7 MW sebelum dan pada saat pengoperasian Unit PLTU Sumbawa Barat 2x7 MW. Tujuan pengukuran suhu air laut sebelum PLTU Sumbawa Barat 2x7 MW yaitu untuk melihat sejauh mana kenaikan suhu air laut ketika air bahang masuk ke perairan laut. Titik sampel yang digunakan sama yaitu 7 titik sampel yang diharapkan dapat memberikan gambaran kondisi perairan di sekitar PLTU Sumbawa Barat 2x7 MW. Hasil pengukuran dapat dilihat pada Tabel 4 
Tabel 4. Suhu air laut sebelum dan pada saat unit PLTU Sumbawa Barat 2x7 MW beroperasi.

\begin{tabular}{llll}
\hline No & Titik Sampel & $\begin{array}{l}\text { Temperatur } \\
\text { Unit beroperasi }\left({ }^{\mathbf{0}} \mathbf{C}\right)\end{array}$ & $\begin{array}{l}\text { Temperatur Pada Saat } \\
\text { Unit beroperasi }\left({ }^{\mathbf{0}} \mathbf{C}\right)\end{array}$ \\
\hline 1. & Intake 1 & 28 & 28 \\
2. & Intake 2 & 28 & 28 \\
3. & Kolam Intake & 30 & 30 \\
4. & Outfall 1 & 30 & 36 \\
5. & Outfall 2 & 28 & 36 \\
6. & Outfall 3 & 28 & 30 \\
7. & Outfall 4 & 28 & 30 \\
\hline
\end{tabular}

Dari hasil penelitian menunjukkan bahwa ada kenaikan suhu air laut yang berhadapan langsung dengan saluran pembuangan air bahang. Dimana jarak antara ujung saluran dengan titik sampel outfall 2 yaitu titik sampling yang berhdapan langsung dengan ujung saluran pembuangan air bahang sejauh 17 meter. Suhu air laut di depan saluran pembuangan naik menjadi $36^{\circ} \mathrm{C}$, kenaikan ini sebesar $8^{\circ} \mathrm{C}$ dari $28^{\circ} \mathrm{C}$ menjada $36^{\circ} \mathrm{C}$ dan melebihi ambang batas air laut yang sudah ditetapkan yaitu maksimum sebesar $32^{\circ} \mathrm{C}$. Kenaikan suhu sebesar $8^{\circ} \mathrm{C}$ dari suhu air laut mula-mula menunjukkan terjadinya pencemaran oleh masuknya air bahang (Fleischli, Steve \& Hayat, Becky: 2014). Peraturan Keputusan Menteri Lingkungan Hidup No.51 Tahun 2004 menyebutkan kenaikan suhu perairan oleh aktivitas industri tidak lebih dari $2^{\circ} \mathrm{C}$ dari suhu perairan mula-mula. Kenaikan suhu sebesar $8^{\circ} \mathrm{C}$ dapat menyebabkan kematian biota laut.

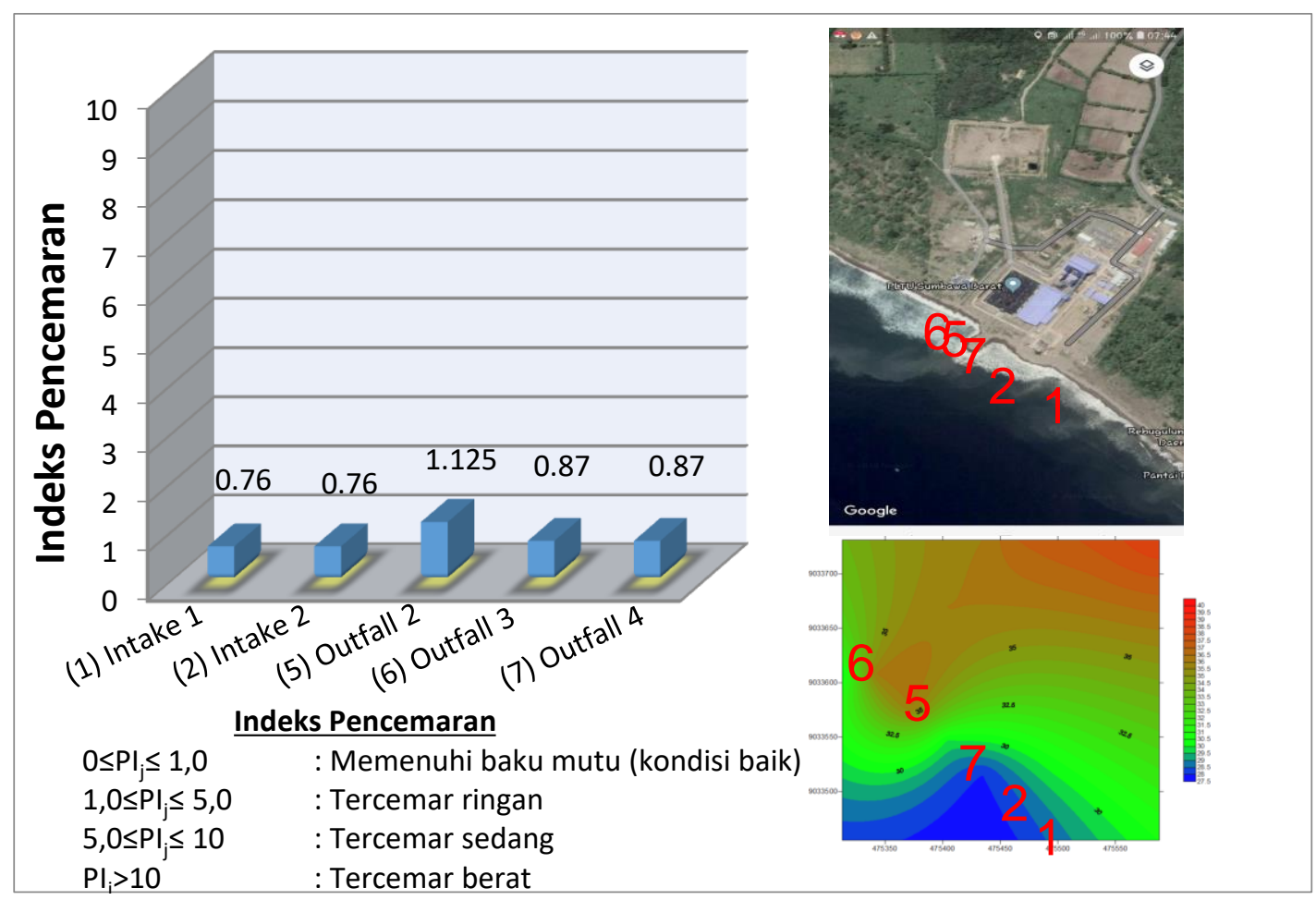


Dari hasil perhitungan diperolah nilai indeks pencemaran $\left(\mathrm{PI}_{\mathrm{j}}\right)$ pada titik sampel yang memiliki suhu paling tinggi yaitu pada Outfall 2 sebesar 1,125. Titik sampel ini berada pada radius 17 meter dari ujung saluran pembuangan air bahang. Artinya bahwa pada radius 17 meter status mutu air laut mengalami pencemaran ringan. Dalam peraturan pemerintah No 82 tahun 2001 menyebutkan bahwa pencemaran air merupakan masuknya atau dimasukkannya makhluk hidup, zat, energi dan atau komponen lain ke dalam air oleh kegiatan manusia, sehingga kualitas air turun sampai ketingkat tertentu sehingga air tidak bisa berfungsi sesuai peruntukannya.

\section{KESIMPULAN}

Secara fisika dan kimia, air bahang PLTU Sumbawa Barat 2x7 MW sudah memenuhi standar baku mutu yang dipersyaratkan yaitu diperoleh nilai rata-rata $\mathrm{pH}$, suhu dan klorin bebas $\left(\mathrm{Cl}_{2}\right)$ secara berurutan sebesar $8,21,38,5^{\circ} \mathrm{C}$ dan $0,03 \mathrm{mg} / \mathrm{L}$. Air bahang PLTU Sumbawa Barat $2 \times 7$ MW dapat mencemari lingkungan perairan sekitar karena dapat menyebabkan naiknya suhu air laut di sekitar saluran pembuangan. Dari hasil perhitungan diperoleh nilai indeks pencemaran ( $\mathrm{PIj}$ ) sebesar 1,125 pada Outfall 2, yang menunjukkan bahwa air laut pada titik ini mengalami pencemaran ringan. 3. Sebaran air bahang PLTU Sumbawa Barat 2x7 MW, mulai dari outfall Condenser sampai perairan sekitar mengalami penurunan suhu, pada panjang saluran pembuangan 303,26 meter, suhu berkurang dari $38,5^{\circ} \mathrm{C}$ menjadi $36^{\circ} \mathrm{C}$

\section{UCAPAN TERIMA KASIH}

Peneliti mengucapkan terima kasih kepada pengelola Pembangkit Listrik Tenaga Uap (PLTU) Sumbawa Barat dan dukungan LPPM Universitas Cordoba sumbawa.

\section{DAFTAR PUSTAKA}

Choi, Keun-Hyung., Kim, Young-Ok., Lee, Joon-Baek., Wang, Soon-Young., Lee, ManWoo., Lee, Pyung-Gang., Ahn, Dong-Sik., Hong, Jae-Sang., and Soh, Ho-Young, 2012, Thermal Impacts Of A Coal Power Plant On The Palnkton In An Coastal Water Environment, Journal of Marine Science and Technology. 20, 2, 187-194.

Effendi, H., 2003,Telaah Kualitas Air bagi Pengelolaan Sumberdaya dan Lingkungan Perairan Cetakan Kelima, Yogyakarta: Kanisius.

Fikri, M. Yuda, 2018, Studi Sebaran Limbah Air Panas PLTU Paiton dari Observasi dan Pemodelan Numerik,Skripsi, Institute Pertanian Bogor.

Fleischli, Steve \& Hayat, Becky, 2014, Power Plant Cooling and Associated Impacts: The Need to Modernize U.S. Power Plants and Protect Our Water Resources and Aquatic Ecosystems, NRDC, IB: 14-04-C.

Hafid, Hasriyani., Noor, Alfian., dan Hamzah, Alimuddin, 2014, Pengaruh Sebaran Suhu Air Pendingin PLTU Jeneponto Terhadap Komunitas Plankton Di Perairan Punagaya, Jeneponto-Sulsel,e-jurnal,http://pasca.unhas.ac.id./jurnal, diakses tanggal 21 Mei 2019.

Hamuna, Baigo., H.R. Tanjung, Rose., Suwito, K. Maury, Hendra., Alianto, 2018, Kajian Kualitas Air Laut dan Indeks Pencemaran Berdasarkan Parameter Fisika-Kimia Di Perairan Distrik Depapre, Jayapura,Jurnal Ilmu Lingkungan, 16, 35-43. 
Kementerian Negara Lingkungan Hidup, 2004, Keputusan Menteri Negara Lingkungan Hidup Nomor 51 Tahun 2004 tentang Baku Mutu Air Laut, Jakarta.

Kementerian Negara Lingkungan Hidup, 2009,Peraturan Menteri Negara Lingkungan Hidup Nomor 8 Tahun 2009 Tentang Baku Mutu Air Limbah Bagi Usaha Dan/Atau Kegiatan Pembangkit Listrik Tenaga Termal, Jakarta.

Megawati, C., Yusuf, M., dan Maslukah, L., 2014, Sebaran Kualitas Perairan Ditinjau dari Zat Hara, Oksigen Terlarut dan $\mathrm{pH}$ di Perairan Selatan Bali Bagian Selatan,Jurnal Oseanografi, 3(2), 142-150.

Nonji, A. 2005.Laut Nusantara. Jakarta: Penerbit Djambatan.

Pemerintah Republik Indonesia, 2001, Peraturan Pemerintah Republik Indonesia Nomor 82 Tahun 2001 Tentang Pengelolaan Kualitas Air dan Pengendalian Pencemaran Air, Jakarta.

PT. PLN(persero) Pusat Pendidikan dan Pelatihan, 2005,Pengoperasian PLTU, Jakarta.

Simanjuntak, M., 2009, Hubungan faktor lingkungan kimia, fisika terhadap distribusi plankton di perairan Belitung Timur, Bangka Belitung,Journal of Fisheries Sciences, 11(1), 31-45. 